Rev. Bras. Saúde Prod. Anim., Salvador, v.16, n.1, p.244-252 jan./mar., 2015 http://www.rbspa.ufba.br ISSN 15199940 http://dx.doi.org/10.1590/S1519-99402015000100025

\title{
Alternative protein sources in nutrition and metabolism of jundiá: in nature and demucilaged linseed meal
}

\author{
Fontes proteicas alternativas na nutrição e metabolismo de jundiás: farelos de linhaça \\ "in natura" e demucilada
}

\section{GOULART, Fernanda Rodrigues ${ }^{1 *}$; SPERONI, Caroline Sefrin ${ }^{2}$; LOVATTO, Naglezi de Menezes $^{1}$; LOUREIRO, Bruno Biach ${ }^{1}$; BENDER, Ana Betine ${ }^{2}$; PRETTO, Alexandra ${ }^{3}$; RADÜNZ NETO, João ${ }^{1}$; SILVA, Leila Picolli da ${ }^{1,2}$}

\author{
${ }^{1}$ Universidade Federal de Santa Maria, Departamento de Zootecnia, Programa de Pós-Graduação em \\ Zootecnia, Santa Maria, Rio Grande do Sul, Brasil. \\ ${ }^{2}$ Universidade Federal de Santa Maria, Departamento de Tecnologia e Ciência dos Alimentos, Programa de \\ Pós Graduação em Ciência e Tecnologia dos Alimentos, Santa Maria, Rio Grande do Sul, Brasil. \\ ${ }^{3}$ Unipampa, Departamento de Zootecnia, Dom Pedrito, Rio Grande do Sul, Brasil. \\ *Endereço para correspondência: fernanda.zoo@bol.com.br
}

\section{SUMMARY}

This study evaluated the growth response and metabolic effects of partial replacement of animal protein source with in natura (LM) or demucilaged (DLM) linseed meal in the diet of jundiá (Rhamdia quelen) juveniles. After demucilagen increased crude protein content and reduced soluble fiber of linseed meal. During seven weeks, 240 jundiá juveniles were reared in water recirculation system and fed to apparent satiation with the following diets: control diet (meat and bones meal and soybean protein concentrate as the main protein sources); $17 \% \mathrm{LM}$ (17\% crude protein of linseed meal replacing meat and bones meal); 17\% DLM (17\% crude protein of demucilaged linseed meal replacing meat and bones meal) or $35 \%$ DLM (35\% crude protein of demucilaged linseed meal replacing meat and bones meal). At the end of the experiment, weight, total and standard length of the animals did not differ between treatments, but lower values of feed conversion were found in the control group. As for metabolic response, animals fed with 35\% DLM diet showed higher level of glucose and cholesterol in plasma, but triglycerides, albumin, total protein and liver biochemistry (glycogen, glucose, lactate, protein, amino acids, ammonia) were not changed between treatments. The results demonstrated that in natura and demucilaged linseed meal can be used in the diet of jundiá without compromising metabolic parameters and final weight.

Keywords: demucilagem, fish, metabolic parameters, Rhamdia quelen

\section{RESUMO}

Este estudo avaliou o crescimento e efeitos metabólicos da substituição parcial da fonte proteica de origem animal pelos farelos de linhaça in natura (FL) e demucilada (FLD) na dieta de juvenis de jundiá (Rhamdia quelen). Após a demucilagem, os níveis de proteína bruta aumentaram e houve redução da fibra solúvel do farelo de linhaça. Durante sete semanas, 240 juvenis de jundiá foram criados em sistema de recirculação de água e alimentados até a saciedade aparente com as seguintes dietas: dieta controle (farinha de carne e ossos e concentrado proteico de soja como as principais fontes proteicas); $17 \% \mathrm{FL}$ (17\% da proteína bruta do farelo de linhaça em substituição da farinha de carne e ossos); $17 \%$ FLD (17\% da proteína bruta do farelo de linhaça demucilada em substituição da farinha de carne e ossos); 35\%FLD (35\% da proteína bruta do farelo de linhaça demucilada em substituição da farinha de carne e ossos). Ao final do experimento, peso e comprimento total e padrão não diferiram entre os tratamentos, porém menores valores de conversão alimentar foram encontrados no grupo controle. Em relação às repostas metabólicas, os animais alimentados com 35\%FLD apresentaram maiores níveis de glicose e colesterol no plasma, porém triglicerídeos, albumina, proteínas totais e os parâmetros bioquímicos do fígado (glicogênio, glicose, lactato, proteína, aminoácidos, amônia) não foram alterados entre os tratamentos. Os resultados demonstraram que tanto o farelo de linhaça in natura como o demucilado podem ser utilizados na dieta de jundiás sem comprometer os parâmetros metabólicos e de peso final.

Palavras-chave: demucilagem, jundiá, parâmetros metabólicos, peixes 
Rev. Bras. Saúde Prod. Anim., Salvador, v.16, n.1, p.244-252 jan./mar., 2015 http://www.rbspa.ufba.br

\section{INTRODUCTION}

The jundiá (Rhamdia quelen) is a fish species that attracts farmers for commercial production purposes, because it easily adapts to artificial diets, and also has good carcass yield, absence of intramuscular bones and favorable characteristics for intensive farming (BALDISSEROTTO \& RADÜNZ NETO, 2004). However, the cost of intensive farming is considered high, mainly due to significant participation of fish meal and meat and bones meal in the composition of their rations, which are increasingly scarce and expensive inputs in the world market (NAYLOR et al., 2009). One way to reduce costs without losing diet quality is to replace sources of animal protein with vegetable protein, whose chemical composition is homogeneous. Furthermore, vegetable ingredients generally have greater availability and lower cost compared to animal meal (BARROSO et al., 2002; PEDRON et al., 2008).

Linseed (Linum usitatissimum L.) is an annual plant grown in cold seasons. After oil is extracted from its seeds, there is meal as a byproduct, whose protein content is high (average 30\%) and raises interest for use in fish nutrition (OOMAH \& MAZZA, 1993). However, the presence of $8 \%$ of the weight seed in water soluble non-starch polysaccharides (NPS) is the main antinutritional characteristic of this protein source (MAZZA \& BILIADERIZ, 1989; RODRÍGUEZ et al., 2001; ALZUETA et al., 2003). The viscous properties of NPS, such as arabinoxylans and $\beta$-glucans, form gum-like masses in the intestine which impairs digestive enzyme activity and nutrient availability of the diet (FRANCIS et al., 2001). Thus, the removal of this component provides enhanced digestibility of linseed meal.

The effect of removing antinutritional factors of feed ingredients in fish nutrition is generally observed by growth indicators, and few studies have evaluated the metabolic profile in fish tissues. Therefore, this study also evaluated the response of biochemical parameters in plasma and liver of jundiá fed with in natura or demucilaged linseed meal in the diet, as well as growth response.

\section{MATERIALS AND METHODS}

The research was conducted at the Laboratory of Fish Culture, Department of Animal Science, Federal University of Santa Maria, Rio Grande do Sul, Brazil. Linseed (variety Normandy) was obtained from the Giovelli Vegetable Oil Industry (Guarani das Missões, RS). The mucilage was extracted from the whole linseed grain in an aqueous medium at a concentration $10 \% \mathrm{w} / \mathrm{v}$, at temperature $60-80^{\circ} \mathrm{C}$ with constant stirring, for 150 minutes. The supernatant was removed and 93\% ethanol (final alcohol concentration of $75 \%$ ) was added in order to precipitate the soluble fiber (MONEGO, 2009). The demucilaged grains were dried in a forced air oven at $50^{\circ} \mathrm{C}$ for 48 hours. The oil of in natura and demucilaged linseed was extracted by washing four times in hexane organic solvent at a concentration of $2: 1(\mathrm{v} / \mathrm{w})$ for 30 minutes for each wash. Dry matter, ash and crude protein as AOAC (1995) and fat content according to Bligh \& Dyer (1959) were measured in in natura and demucilaged linseed meal. The levels of total dietary fiber (TF) and insoluble fiber (IF) were determined according to AOAC (1995), (enzymatic-gravimetric method number 991.43), and soluble 
Rev. Bras. Saúde Prod. Anim., Salvador, v.16, n.1, p.244-252 jan./mar., 2015 http://www.rbspa.ufba.br ISSN 15199940

fiber (SF) was determined by difference. The amino acid profile of meals was evaluated by High Performance Liquid Chromatography (HPLC) as Bernal et al. (2008).
The extraction yield of linseed mucilage was calculated using the following mathematical formula:

$\%$ yield of extraction $=$

Mucilaged obtained grams x 100

Sample weight (linseed)

For the feeding test, 240 jundiá juveniles were used; they were divided into twelve polypropylene boxes (280 liters of useful volume each), and arranged in a recirculating water system with two biological filters and reservoir, with controlled temperature and aeration system. Twenty animals were used per experimental unit, with $14.49 \pm$ 1.85 grams and $11.74 \pm 0.61 \mathrm{~cm}$ as initial measures. The fish were fed for seven weeks with isocaloric and isonitrogenous diets, where the in natura or demucilaged meal linseed partially replaced the source of animal protein. The experimental design was completely randomized with three replications for each of four treatments: 17\% LM: $17 \%$ crude protein of in natura linseed meal replacing meat and bones meal; $17 \%$ DLM: $17 \%$ crude protein of demucilaged linseed meal replacing meat and bones meal; 35\% DLM: $35 \%$ crude protein of demucilaged linseed meal replacing meat and bones meal (Table 1). The calculated essential amino acid concentrations in the experimental diets (Table 2) followed the recommendation of Montes-Girao \& Fracalossi (2006). For the sake of comparison, a control diet was used with meal and bones meal and soybean protein concentrate as the main protein sources. The experimental diets were given to the fish three times a day, at 9, 13 and 17 hours, until the animals were fed to satiation. At 8 and
16 hours, food residue and fish waste were removed from the experimental units.

Water quality was monitored daily for temperature and dissolved oxygen (oximetry pulse; YSI Yellowsprings USA) and weekly for $\mathrm{pH}$, total ammonia, total alkalinity and hardness using colorimetric kit Alfakit®, and nitrite according to Boyd \& Tucker (1992). Water quality parameters during the experiment were as follows: temperature: $24.9 \pm 1.51^{\circ} \mathrm{C}$; dissolved oxygen: $6.72 \pm 0.43 \mathrm{ppm}$; pH: $7.28 \pm$ 0.25 ; total ammonia: $0.1 \pm 0.06 \mathrm{ppm}$; alkalinity: $48.77 \pm 13.70 \mathrm{mg} / \mathrm{L} \mathrm{CaCO}_{3}$; hardness: $56.38 \pm 34.61 \mathrm{mg} / \mathrm{L} \mathrm{CaCO}_{3}$ and nitrite: $0.1 \pm 0.1 \mathrm{ppm}$. All parameters remained within the optimum range for farming jundiá (BALDISSEROTTO \& RADÜNZ NETO, 2004).

After seven weeks of feeding, the animals were fasted for 24 hours and blood samples were taken from three juveniles per experimental unit, by puncturing the vessel flow, using heparinized syringes previously. The blood was centrifuged to obtain the plasma for analysis of glucose, triglycerides, cholesterol, total circulating protein and albumin using commercial colorimetric kits (Doles). After blood sampling, fish were killed by spinal cord excision and their liver was collected for biochemical analysis. Thus, the tissue was fractioned into 50 
Rev. Bras. Saúde Prod. Anim., Salvador, v.16, n.1, p.244-252 jan./mar., 2015 http://www.rbspa.ufba.br ISSN 15199940

mg samples to quantify glycogen (KRISMAN, 1962), glucose (PARK \& JOHNSON, 1949), lactate (HARROWER \& BROWN, 1972), protein (LOWRY et al., 1951), free amino acids (COPLEY, 1941) and ammonia (VERDOUW et al., 1978). The remaining animals in each box were anesthetized with eugenol $\left(20 \mu \mathrm{L}\right.$ of pure extract $\mathrm{L}^{-1}$ water) to collect data on weight $(\mathrm{g})$, total and standard length $(\mathrm{cm})$ and also to calculate feed conversion.

The data were subjected to analysis of variance and the F-test, and means were compared by Tukey's test at 5\% significance level. The results of the plasma parameters are expressed as mean \pm standard error of mean and other data as mean \pm standard deviation.

Table 1. Formulation and proximate composition of experimental diets

\begin{tabular}{|c|c|c|c|c|}
\hline \multirow{2}{*}{ Ingredients (\%) } & \multicolumn{4}{|c|}{ Treatments $^{4}$} \\
\hline & Control & $17 \% \mathrm{LM}$ & $17 \%$ DLM & $35 \%$ DLM \\
\hline Meat and bone meal & 30 & 24.9 & 24.9 & 19.5 \\
\hline Corn & 19.5 & 20 & 20 & 15 \\
\hline Defatted rice bran & 3.7 & 2.5 & 3,0 & 0 \\
\hline Soybean protein concentrate & 26 & 25 & 25 & 26.3 \\
\hline Linseed meal & 0 & 10.57 & 0 & 0 \\
\hline Demucilaged linseed meal & 0 & 0 & 9.45 & 19.45 \\
\hline Corn starch & 2.4 & 2.7 & 5.2 & 8 \\
\hline Soybean oil & 3.5 & 3 & 5.5 & 8.5 \\
\hline Vitamin and mineral premix ${ }^{1}$ & 3 & 3 & 3 & 3 \\
\hline Dicalcium phosphate & 3.64 & 1.5 & 1.19 & 0 \\
\hline Monosodium glutamate & 0.25 & 0.25 & 0.25 & 0.25 \\
\hline Butil hydroxy toluene (BHT) & 0.01 & 0.01 & 0.01 & 0.01 \\
\hline Limestone & 2.2 & 1,5 & 1.2 & 0 \\
\hline Inert & 5.8 & 5.07 & 1.3 & 0 \\
\hline DL- methionine & 0 & 0.21 & 0.21 & 0.094 \\
\hline \multicolumn{5}{|l|}{ Diet composition $^{2}$} \\
\hline Moisture & 5.58 & 5.61 & 5.40 & 4.60 \\
\hline Crude protein & 37.11 & 36.25 & 36,34 & 36.20 \\
\hline Fat & 10.34 & 10.59 & 12.61 & 15.70 \\
\hline Neutral detergent fiber & 6.31 & 11.65 & 9.72 & 12.77 \\
\hline Mineral matter & 10.21 & 13.48 & 7.87 & 6.03 \\
\hline Calcium & 3.78 & 2.68 & 2.48 & 1.40 \\
\hline Total phosphorus & 1.99 & 1.42 & 1.35 & 0.85 \\
\hline Digestible energy $(\mathrm{kcal} / \mathrm{kg})^{3}$ & 3218 & 3201 & 3200 & 3183 \\
\hline
\end{tabular}

${ }^{\mathrm{T}}$ Vitamin and mineral premix (per Kg of product): Folic acid: $299.88 \mathrm{mg}$; Ascorbic acid: $15.000 .12 \mathrm{mg}$, Pantothenic: $3.000 .10 \mathrm{mg}$, Biotin: $0.06 \mathrm{mg}$, Niacin(B3): $9.000 .32 \mathrm{mg}$, Choline (B4):103.500.00 mg, Vit A: $1.000 .000 .00 \mathrm{UI}, 10.000 .00 \mathrm{mg}$, Vit. K3: $400.00 \mathrm{mg}$. Inositol: $9.999 .92 \mathrm{mg}$, Iron: 6.416 .80 , Manganese: $8.000 .40 \mathrm{mg}$, Copper: $1.000 .00 \mathrm{mg}$, Zinc: $13.999 .50 \mathrm{mg}$, Iodine: $45.36 \mathrm{mg}$, Cobalt:60.06 mg, Selenium: $60.30 \mathrm{mg}$, Magnesium:5.10 mg, Chlorine: $2.30 \%$,Sulphur: $0.01 \%$.

${ }^{2}$ Values calculated and expressed as fed.

${ }^{3}$ Calculated: Digestible Energy $=[(\mathrm{CP} * 5.65 * 0.85)+(\mathrm{EE} * 9.4 * 0.9)+(0.7 * 4.15 * \mathrm{CSDN})]($ adjusted to MEYER et al. 2004).

${ }^{4}$ Treataments: $17 \%$ LM: $17 \%$ crude protein of in natura linseed meal replacing meat and bones meal; 17\% DLM and 35\% DLM: 17 and 35\% crude protein of demucilaged linseed meal replacing meat and bones meal, respectively. 
Rev. Bras. Saúde Prod. Anim., Salvador, v.16, n.1, p.244-252 jan./mar., $2015 \quad$ http://www.rbspa.ufba.br ISSN 15199940

Table 2. Calculated amino acid composition of diets used in the study (\% in diet)

\begin{tabular}{lcccc}
\hline \multirow{2}{*}{ Amino acids } & \multicolumn{4}{c}{ Treatments $^{1}$} \\
\cline { 2 - 4 } & Control & $17 \%$ LM & $17 \%$ DLM & $35 \%$ DLM \\
\hline Lysine & 2,02 & 1,94 & 1,95 & 1,91 \\
Met + Cys & 1,37 & 1,35 & 1,34 & 1,34 \\
Threonine & 1,30 & 1,25 & 1,17 & 1,07 \\
Tryptophane & 0,13 & 0,11 & 0,11 & 0,09 \\
Valine & 1,66 & 1,58 & 1,47 & 1,35 \\
Isoleucine & 1,25 & 1,26 & 1,16 & 1,97 \\
Leucine & 2,36 & 2.31 & 2,16 & 1,28 \\
Phenylalanine & 1,47 & 1,45 & 1,37 & 0,76 \\
Histidine & 0,95 & 0,92 & 0,84 & 1,77 \\
Arginine & 2,20 & 2,21 & 1,96 & \\
\hline 'Treataments: 17\% LM: $17 \%$ crude protein of in natura linseed meal replacing meat and bones meal; \\
17\% DLM and 35\% DLM: 17 and 35\% crude protein of demucilaged linseed meal replacing meat and \\
bones meal, respectively.
\end{tabular}

\section{RESULTS AND DISCUSSION}

The average yield of extraction of the linseed mucilage used in the composition of the diets tested was 7.18 $\pm 1.54 \%$, which is consistent with the results found by Monego (2009). The process of extracting the mucilage decreased by approximately $50 \%$ the soluble fiber content of linseed meal (Table 3). Furthermore, the process of demucilagen also resulted in increase of crude protein, essential amino acids and decrease in the concentration of minerals, which is consistent with the results found by Alzueta et al. (2003). Removal of most of the mucilaginous material from linseed by extraction with hot water markedly increased its nutritive value.

In relation to growth indicators, the partial replacement of meat and bone meal with in natura or demucilaged linseed meal caused no differences in weight, standard and total length among animals. In this study, the balance of essential amino acids (Table 3), mainly lysine and methionine, may have led to similar final weight in all the treatments. El-Saidy \& Gaber (2003) evaluated the substitution of fish meal with protein vegetable in diet of the Nile tilapia (Oreochromis niloticus) and also observed no significant differences in final weight between animals fed diets containing plant protein mixture, compared with the control group.

Table 3. Nutritional characteristics of in natura and demucilaged linseed meal

\begin{tabular}{lcc}
\hline Component & LM & DLM \\
\hline Crude protein (\%) & 29.06 & 32.08 \\
Fat (\%) & 16.92 & 13.89 \\
Total fiber (\%) & 37.06 & 36.61 \\
Soluble fiber (\%) & 11.95 & 6.09 \\
Insoluble fiber (\%) & 25.10 & 30.53 \\
Mineral matter (\%) & 5.21 & 4.75 \\
Dry matter (\%) & 95.58 & 97.88 \\
\hline Essential amino acids & & \\
\hline Lysine (\%) & 1 & 1.12 \\
Methionine+cysteine (\%) & 1.68 & 1.84 \\
Threonine (\%) & 0.88 & 1.09 \\
Valine (\%) & 1.08 & 1.28 \\
Isoleucine (\%) & 0.97 & 1.11 \\
Leucine (\%) & 1.55 & 1.79 \\
Phenylalanine (\%) & 0.76 & 0.95 \\
Histidine (\%) & 0.89 & 0.95 \\
Arginine (\%) & 2.42 & 3.01 \\
\hline Data (n=3) expressed in natural matter. LM $=$ \\
in natura linseed meal; DLM = demucilaged \\
linseed meal.
\end{tabular}


Rev. Bras. Saúde Prod. Anim., Salvador, v.16, n.1, p.244-252 jan./mar., $2015 \quad$ http://www.rbspa.ufba.br ISSN 15199940 http://dx.doi.org/10.1590/S1519-99402015000100025

Table 4. Growth variables and biochemical parameters in tissues of jundiá juveniles fed for seven weeks on diets containing in natura or demucilaged linseed meal

\begin{tabular}{lcccc}
\hline Variables $^{3}$ & Control & $17 \% \mathrm{LM}$ & $17 \%$ DLM & $35 \%$ DLM \\
\hline Growth $^{1}$ & & & \\
\hline Weight $(\mathrm{g})$ & $45.74 \pm 11.64$ & $47.13 \pm 13.74$ & $48.71 \pm 13.3$ & $45.97 \pm 13.44$ \\
Total length $(\mathrm{cm})$ & $16.34 \pm 1.45$ & $16.72 \pm 1.40$ & $16.5 \pm 1.39$ & $16.52 \pm 1.39$ \\
Standard lenght $(\mathrm{cm})$ & $13.59 \pm 1.37$ & $13.87 \pm 1.19$ & $13.71 \pm 1.19$ & $13.67 \pm 1.26$ \\
Feed conversion & $1.12 \pm 0.12^{\mathrm{b}}$ & $1.40 \pm 0.11^{\mathrm{a}}$ & $1.41 \pm 0.10^{\mathrm{a}}$ & $1.36 \pm 0.11^{\mathrm{a}}$ \\
\hline Plasma $^{2}$ & & & \\
\hline GLU $\left(\mathrm{g} \mathrm{dL}^{-1)}\right.$ & & & \\
TG $\left(\mathrm{mg} \mathrm{dL}^{-1}\right)$ & $50.12 \pm 2.41^{\mathrm{b}}$ & $56.52 \pm 3.68$ & $54.22 \pm 2.74^{\mathrm{ab}}$ & $62.71 \pm 5.16^{\mathrm{a}}$ \\
CHOL $\left(\mathrm{mg} \mathrm{dL}^{-1}\right)$ & $765.6 \pm 102.5$ & $642.9 \pm 78.6$ & $789.7 \pm 86.9$ & $871.4 \pm 78.0$ \\
PROT $\left(\mathrm{g} \mathrm{dL}^{-1}\right)$ & $130.71 \pm 3.24^{\mathrm{b}}$ & $121.3 \pm 6.6^{\mathrm{b}}$ & $129.6 \pm 2.9^{\mathrm{b}}$ & $178.7 \pm 10.7^{\mathrm{a}}$ \\
ALBM $\left(\mathrm{g} \mathrm{dL}^{-1}\right)$ & $4.12 \pm 0.19$ & $4.21 \pm 0.21$ & $4.15 \pm 0.18$ & $4.73 \pm 0.38$ \\
\hline Liver & $0.82 \pm 0.06$ & $0.89 \pm 0.15$ & $0.76 \pm 0.05$ & $0.78 \pm 0.07$ \\
\hline GLY $(\%)$ & & & \\
GLUH $\left(\mu \mathrm{mol} \mathrm{g}^{-1}\right)$ & $9.46 \pm 4.0$ & $7.08 \pm 3.66$ & $6.21 \pm 4.06$ & $5.78 \pm 2.47$ \\
LAC $\left(\mu \mathrm{mol} \mathrm{g}^{-1}\right)$ & $31.32 \pm 4.94$ & $32.24 \pm 5.94$ & $24.63 \pm 3.45$ & $31.21 \pm 8.86$ \\
PROTH $\left(\mathrm{mg} \mathrm{g}^{-1}\right)$ & $9.47 \pm 2.74$ & $8.62 \pm 1.90$ & $9.86 \pm 3.54$ & $8.29 \pm 1.88$ \\
AA $\left(\mu \mathrm{mol} \mathrm{g}^{-1}\right)$ & $25.46 \pm 4.33$ & $19.21 \pm 8.12$ & $21.14 \pm 6.97$ & $24.28 \pm 3.18$ \\
AM $\left(\mu \mathrm{mol} \mathrm{g}^{-1}\right)$ & $65.31 \pm 45.78$ & $50.18 \pm 15.72$ & $78.17 \pm 42.14$ & $85.44 \pm 60.03$ \\
\hline
\end{tabular}

${ }^{\mathrm{T}}$ Values expressed as mean \pm standard deviation and; ${ }^{2}$ mean \pm standard error of mean $(\mathrm{n}=9)$. Different letters in the lines of the table represent significant differences by Tukey's test ( $p<0.05)$. ${ }^{3} \mathrm{GLU}=$ glucose; $\mathrm{TG}=$ Triglycerides; $\mathrm{CHOL}=$ Cholesterol; $\mathrm{PROT}=$ total protein; $\mathrm{ALBM}=$ albumin; $\mathrm{GLY}=$ glycogen; $\mathrm{GLUH}=$ hepatic glucose; $\mathrm{LAC}=$ lactate; $\mathrm{PROTH}=$ hepatic protein; $\mathrm{AA}=$ amino acids; $\mathrm{AM}=$ ammonia. $17 \%$ LM: 17\% crude protein of in natura linseed meal replacing meat and bones meal; 17\% DLM and 35\% DLM: 17 and 35\% crude protein of demucilaged linseed meal replacing meat and bones meal, respectively.

Satisfactory results of growth obtained in the treatment $17 \%$ LM may be associated with the prebiotic effect of the mucilage of the in natura meal. The soluble fiber of linseed may stimulate the growth and activity of beneficial bacteria, producing positive effects on animal performance (ALZUETA et al., 2003). Furthermore, the feeding habits of jundiá, which is an omnivorous species, may have contributed to effective use of plant ingredients. Similarly, Pedron et al. (2008) observed no effect of the sources and levels of fiber for the variables of growth in jundiá.

The fish that received the control diet had better feed conversion compared with other treatments (Table 4). However, the results found for feed conversion in treatments $17 \% \mathrm{LM}, 17 \%$ DLM and 35\% DLM can be considered acceptable, because these values are not always achieved for captive bred animals receiving only artificial feeding. According to Losekann et al. (2008), feed conversion values between 1.3-1.5 are considered acceptable for the species under study.

Considering the parameters evaluated in plasma, the inclusion of different forms of linseed meal in the diet of jundiá did not alter the levels of triglycerides, total protein and albumin (Table 4). Animals of the $35 \%$ DLM treatment showed higher blood glucose compared with the control fish treatment. According to Borges et al. (2004), glucose values found in fish in this study were within the range considered normal for the species (43 to $78 \mathrm{mg} / \mathrm{dL}$ ). Most of the fish have a behavior similar to that of diabetic animals; in other words, even 
when small amounts of carbohydrates are included in their diet, their response may be marked by significant increase in blood glucose levels (BACILA, 2003). Higher levels of cholesterol were found in the 35\% DLM diet compared with other treatments and numerically lower values were observed in the $17 \%$ LM treatment. This result may be associated with greater inclusion of soybean oil in this diet to maintain similar levels of energy between treatments. Corrêia et al. (2012) found lower levels of blood total cholesterol for jundiá juveniles and common carp fed with plant sources such as oat bran and defatted rice meal. This hypocholesterolemic effect on the $17 \%$ LM diet is related to the ability of fibers to absorb bile acids, which causes increased deflection of the endogenous cholesterol to a new synthesis of fatty acids. Furthermore, fibers have the characteristic of increasing fecal mass by decreasing the absorption and levels of serum cholesterol and glucose (MEURER \& HAYASH 2003; FOOD INGREDIENTS BRASIL, 2008).

Just like the biochemical response measured in the plasma, some parameters of the hepatic metabolism may be good indicators of the animal's response to a particular feed. In this study, no changes were observed for glycogen, glucose, lactate, protein, amino acids and ammonia in the hepatic tissue of silver catfish (Table 4). Glycogen is a form of carbohydrate reserves broken down to glucose in the liver for energy supply (BARCELLOS et al., 2010). The inclusion of plant protein in the diet of jundiá did not promote significant difference in glycogen stores between treatments, suggesting that the fish spent similar levels of this metabolite to maintain glucose circulating. Endogenous or exogenous amino acids are also directed to the production of energy. This most commonly occurs when diets are deficient in lipids and carbohydrates or fish species have reduced ability to extract energy from such sources (LUNDSTEDT et al., 2004). Excessive protein level of feeds and the use of amino acids to produce glucose can increase the concentration of ammonia in tissues and signal the misuse of dietary protein. Similar metabolic results found in jundiá juveniles suggest that the level and the source of plant protein used in the diets had the same efficiency in the metabolism of animals receiving higher levels of animal protein source. The similar growth shown by the fish is also connected to this fact. Thus, the assessment of metabolic parameters in fish serves as an indicator of nutritional status, and it is also an important contribution to the nutrition and farming of these animals.

In conclusion, the demucilaged process in linseed meal increased nutrients and essential amino acids, improving their nutritional composition. Despite obtain worst feed conversion, our findings suggest that both forms in natura as demucilaged of the linseed meal could replace $17 \%$ and $35 \%$, respectively, meat and bone meal protein in the diets for jundiá juveniles without causing adverse effects on weight and fish metabolism for up to 7 weeks.

\section{ACKNOWLEDGEMENTS}

The authors of this study would like to thank CAPES (Coordination for the Improvement of Higher Education Personnel) for the graduate student stipend awarded to the first author, and CNPq (National Council for Scientific and Technological Development) for the scholarships and undergraduate research productivity grants. We are also thankful to Giovelli Vegetable Oil Industry for donating the linseed for the experiment. 
Rev. Bras. Saúde Prod. Anim., Salvador, v.16, n.1, p.244-252 jan./mar., 2015 http://www.rbspa.ufba.br ISSN 15199940 http://dx.doi.org/10.1590/S1519-99402015000100025

\section{REFERENCES}

ALZUETA, C.; RODRIGUEZ, M.L.; CUTULI, M.T.; REBOLÉ, A.; ORTIZ, L.T.; CENTENO, C.; TREVIÑO, J. Effect of whole and demucilaged linseed in broiler chicken diets on digesta viscosity, nutrient utilization and intestinal microflora. British Poultry Science, v.44, p.67-74, 2003

ASSOCIATION OF OFFICIAL ANALYTICAL CHEMISTRY - AOAC. Official Methods of Analyses of the AOAC International. 16. ed. Washington, 1998.1018p.

\section{BACILA, M. Bioquímica Veterinária.} 2.ed. Rio de JAneiro: Robe.2003.

BALDISSEROTTO, B.; RADÜNZ NETO, J. Criação de jundiá. Santa Maria: Universidade Federal de Santa Maria, 2004. 232p.

BARCELLOS, L.J.G.; MARQUEZE, A.; TRAPP, M.; QUEVEDO, R.M.; FERREIRA, D. The effects of fasting on cortisol, blood glucose and liver and muscle glycogen in adult jundiá Rhamdia quelen. Aquaculture, v.300, p.231-236, 2010.

BARROSO, M.V.; CASTRO, J.C.; AOKI, P.C.M.; HELMER, J.L.Valor Nutritivo de Alguns Ingredientes para o Robalo (Centropomus parallelus). Revista Brasileira de Zootecnia, v.31, p.21572164, 2002.

BERNAL, J.L.; NOZAL, M.J.; TORIBIO, L.; DIEGO, C.; MAYO, R.; MAESTRE, R. Use of supercritical fluid extraction and gas chromatographymass spectrometry to obtain amino acid profiles from several genetically modified varieties of maize and soybean. Journal of Chromatography A, v.1192, p.266-272, 2008.
BLIGH, E.G.; DYER, W.J. Rapid method of total lipid extraction and purification.

Canadian Journal of Biochemistry and Physiology, v.37, p.911-917, 1959.

BOYD, E.; TUCKER, C.S. Walter quality and pond soil analyses for aquaculture. Auburn: University, Auburn, 1992. 300p.

BORGES, A.; SCOTTI, L.V.; SIQUEIRA, D.R. Hematologic and serum biochemical values for jundiá (Rhamdia quelen). Fish Physiology and Biochemistry, v.30, n.21-25, 2004.

COPLEY, N.G. Alloxan and ninhydrin test. The Analyst, v.66, p.492-493, 1941.

CORRÊIA, V.; SILVA, L. P.; PEDRON, F. A.; LAZZARI, R.; FERREIRA, C. C.; RADÜNZ NETO, J. Fontes energéticas vegetais para juvenis de jundiá e carpa.

Arquivo Brasileiro de Medicina Veterinária e Zootecnia, v.64, n.3, p.693-701, 2012.

EL-SAIDY, D.; GABER, M.M.A.

Replacement of fish meal with a mixture of different plant protein sources in juvenile Nile tilapia, Oreochromis niloticus (L.) diets. Aquaculture

Research, v.34, n.13, p.1119-1127, 2003.

FOOD INGREDIENTS BRASIL. [2008]. Dossiê de fibras alimentares. Available at: $\langle\mathrm{http}: / / \mathrm{www}$. revistafi.com/materias/63.pdf $>$. Accessed on: Dez. 12, 2011.

FRANCIS, G.; MAKKAR, H.P.S.; BECKER, K. Antinutritional factors present in plant-derived alternate fish feed ingredients and their effects in fish. Aquaculture, v.199, p.197-227, (2001).

HARROWER, J.R.; BROWN, C.H. Blood lactic acid. A micromethod adapted to field collection of microliter samples. Journal of Applied Physiology, v.32, p.224-228, 1972. 
Rev. Bras. Saúde Prod. Anim., Salvador, v.16, n.1, p.244-252 jan./mar., 2015 http://www.rbspa.ufba.br ISSN 15199940

KRISMAN, C.R. A method for the colorimetric estimation of glycogen with iodine. Analytical Biochemistry, v.4, p.17-23, 1962.

LOSEKANN, M.E.; RADÜNZ NETO, J.; EMANUELLI, T.; PEDRON, F.A.; LAZZARI, R.; BERGAMIN, G.T.; CORRÊIA, V.; SIMÕES, R.S.

Alimentação do jundiá com dietas contendo óleos de arroz, canola ou soja. Ciência Rural, v.38, p.225-230, 2008.

LOWRY, D.H.; ROSEBROUGH, N.J.; FARR, A.L. Protein measurement with folin phenol reagent. Journal of Biological Chemistry, v.193, p.265-275, 1951.

LUNDSTEDT, L.M.; MELO, J.F.B.; MORAES, G. Digestive enzymes and metabolic profile of Pseudoplatystoma corruscans (Teleostei: Siluriformes) in response to diet composition.

Comparative Biochemistry and Physiology, v.137, p.331-339, 2004.

MAZZA, G.; BILIADERIS, C.G. Functional properties of flax seed mucilage. Journal of Food Science, v.54, p.1302-1305, 1989.

MEYER, G.; FRACALOSSI, D.M.; BORBA, M.R. A importância da quantidade de energia na ração de peixes.

Panorama da Aqüicultura, v.14, p.53-57, 2004.

MEURER, F.; HAYASH, C.

Polissacarídeos não amiláceos na nutrição de peixes - revisão. Arquivos de Ciências Veterinárias e Zoologia da UNIPAR, v.6, p.217-138, 2003.

MONEGO, M.A. Extração de fibra solúvel de torta de linhaça para uso como hidrocolóide na indústria de alimentos. 2009. 89p. Dissertação (Mestrado em Ciência e Tecnologia dos Alimentos) - Universidade Federal de Santa Maria, Santa Maria.
MONTES-GIRAO, P. J.; FRACALOSSI, D.M. Dietary lysine requerimento as basis to estimate the essential dietary amino acid profile for jundiá Rhamdia quelen.

Journal of World Aquaculture Society, v.37, n.4, p.388-396, 2006.

NAYLOR, R.L.; HARDY, R.W.;

BUREAU, D.P. Feeding aquaculture in na era of finite resources. Proceedings of the National Academy of Sciences of the United States of America, v.106, p.1510315110, 2009.

OOMAH, B.D.; MAZZA, G. Flaxseed proteins - a review. Food Chemistry, v.48, p.109-114, 1993.

PARK, J.T.; JOHNSON, M.J. A submicro determination of glucose. Journal of Biological Chemistry, v.181, p.149-151, 1949.

PEDRON, F.A.; RADÜNZ NETO, J.; EMANUELLI, T.; SILVA, L.P.; LAZZARI, R.; CORRÊIA, V.; BERGAMIN, G.T.; VEIVERBERG, C.A. Cultivo de jundiás alimentados com dietas com casca de soja ou de algodão. Pesquisa Agropecuária Brasileira, v.43, p.93-98, 2008.

RODRÍGUEZ, M.L.; ALZUETA, C.; REBOLE, A.; ORTIZ, L.T.; CENTENO, C.; TREVINO, J. Effect of inclusion level of linseed on the nutrient utilization of diets growing broiler chickens. British Poultry Science, v.42, p.368-375, 2001.

VERDOUW, H.; VANECHTELD, C.J.A.; DECKKERS, E.M.J. Ammonia determinations based on indophenol formation with sodium salicylate. Water Research, v.12, p.399-402, 1978.

Data de recebimento: 31/03/2014

Data de aprovação: 10/03/2015 